\title{
Corrosion Effects on the Grounding Resistance of Grounding System Buried in Two-Layers Soil
}

\author{
Osama E. Gouda \\ Electrical Engineering Department \\ Faculty of Engineering \\ Cairo University, Cairo, Egypt \\ prof_ossama11@yahoo.com \\ Ahmed E. Kalas \\ Electrical Engineering Department \\ Faculty of Engineering \\ Port Said University \\ Port - Said, Egypt. \\ okalas_14@yahoo.com
}

\author{
Sobhy S. Dessouky \\ Electrical Engineering Department \\ Faculty of Engineering \\ Port - Said University \\ Port - Said, Egypt \\ sobhyserry@yahoo.com \\ Mohamed A. Hamdy \\ Electrical Engineering Department \\ Faculty of Technology \\ Worker's University \\ Ismailia, Egypt \\ enghamdym@yahoo.com
}

\begin{abstract}
Corrosion of the grounding grid is the most defective parameter, which has appreciable effect on the grounding grid performance and its ability to ensure its main target of stability and safety of the electrical systems. Mathematical model is used to investigate the corrosion degree of the grounding grid, and its effect on the grid current distribution and the grounding grid lifetime. The study is applied to different shapes of steel grounding grids buried in two layers soil. Moreover, an experimental study is carried out to investigate the relationship between the corrosion degree and the contact resistance of the galvanized steel grounding grid for different shapes at low resistivity conditions.
\end{abstract}

Key Words - Corrosion degree, current distribution, steel grounding grid, two layers soil.

\section{INTRODUCTION}

Some numerical and analytical methods [1-5] were proposed to evaluate the ground resistance and other parameters of the steel grounding grids. Numerical methods considered the potential of the grounding grid surface is not zero. Grounding grid may not be considered equipotential surface only occur when the grid networks are large or the frequency is very high. Most of the industrial grounding girds are small and medium size and the significant parameters are not calculated with very high frequency. So, it may be assumed that all segments of grounding grids are at the same potential under fault conditions [3]. However, all of the previous methods [5-10] can only be applied when the grounding grid is in good conditions without any performance degradation and cannot be used to evaluate the performance of the grounding grid at a certain year after the grounding grid has been put into service.

Grounding system buried underground is subject to very harsh conditions and may easily become corroded. In fact, the ground resistance of the grounding grid and other parameters will become worse over time according to corrosion. When the performance of a grounding gird can no longer meet the requirements, the grid does not serve its purpose [4]. Ideally, the grounding grid should have a service life equal to that of the industrial facility. Therefore, when a grounding grid is in the initial design, the service life of the grounding grid and its performance, as well as current distribution of each segment of the grounding grid at a certain year subsequently, has been put into service need to be calculated or estimated. The estimated lifetime can help establish more economical maintenance strategy of the grounding grid, nevertheless, there is a general lack of the methods or schemes that can provide the calculations or estimations of the grounding grid performance at a certain year after has been put into service [5].

This paper discusses, as a new contribution, the corrosion effects on the distribution of grounding grid currents and service lifetime in a two-layer soil model.

According to the relevant research [11-15] of electrical contact, the contact resistance $\left(R_{\text {cont }}\right)$ of the grounding grid is increasing due to corrosion effect because of two main reasons:

1- Corrosion will affect the surface roughness of conductor segment of the grid and increases the contact resistance between the conductor segments and soil.

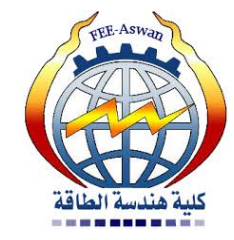


2- Corrosion will make the surface of conductor segments covered with a layer of an oxide film. The oxide film with high resistance increases the contact resistance between the conductor segment and soil.

In this paper, experimental and numerical study is carried out to indicate the relationship between the corrosion degree $(\eta)$ and the contact resistance $\left(R_{\text {cont }}\right)$ of the galvanized steel grounding grid with different shapes. Moreover, service lifetime estimation for small and medium-sized grounding girds is indicated.

At a certain year after the grounding grid has been buried in the soil, the proposed method is used to evaluate the performances of the galvanized steel grounding grid with different shapes and the current distribution passing through each segment of the grid can be estimated.

\section{MAthematicAl Model}

In this paper, the grounding grid in two layers soil model is divided into $n$ segments at the same potential under fault conditions. According to the difference between the upper and lower soil resistivity values, the grounding grid divided with the assumption that the corrosion rate $(v)$ of the grid conductor segments is the same but it is different from the corrosion rate of the grid rod segments. This assumption is acceptable in small and medium-size grounding grids because of the soil conditions are changing constantly[3].

The corrosion rate $(v)$ can be estimated based on historical data [4]. The corrosion rate is associated with the material specification that buried in specified soil conditions. The corrosion rate is affected by the following soil parameters: soil resistivity, $p H$ value, moisture content, aeration, and miscellaneous. A general equation including the effects of all of the above parameters is provided in the following equation [4]:

$$
v=f\left(\rho, x_{1}, x_{2}, x_{3}\right)
$$

\section{Where:}

$v:$ is the corrosion rate (mils/yr.)

$\rho:$ is the soil resistivity $(\Omega-\mathrm{cm})$

$x_{1}$ : is the $p H$ value

$x_{2}:$ is the soil moisture content $(\%)$

$x_{3}:$ is the aeration $(\%)$

Using simple multiple regression analyses, the following equation is obtained for estimation of the corrosion of steel in any environment [4]:

$$
\begin{aligned}
& v=3.36-\left(9.63 \times 10^{-5}\right) \times \rho+0.29 x_{1}+ \\
& 0.034 x_{2}+0.012 x_{3}
\end{aligned}
$$

This equation is obtained from experimental data and is limited by extreme corrosion conditions, such as extremely high resistivity $(>10,000 \Omega-\mathrm{cm})$ or extremely low aeration quantities $(<3 \%)$. It is experimentally, found that the average corrosion rate in the following 12 years reduces to half of that value in the first 12 years and it is negligible thereafter [4].

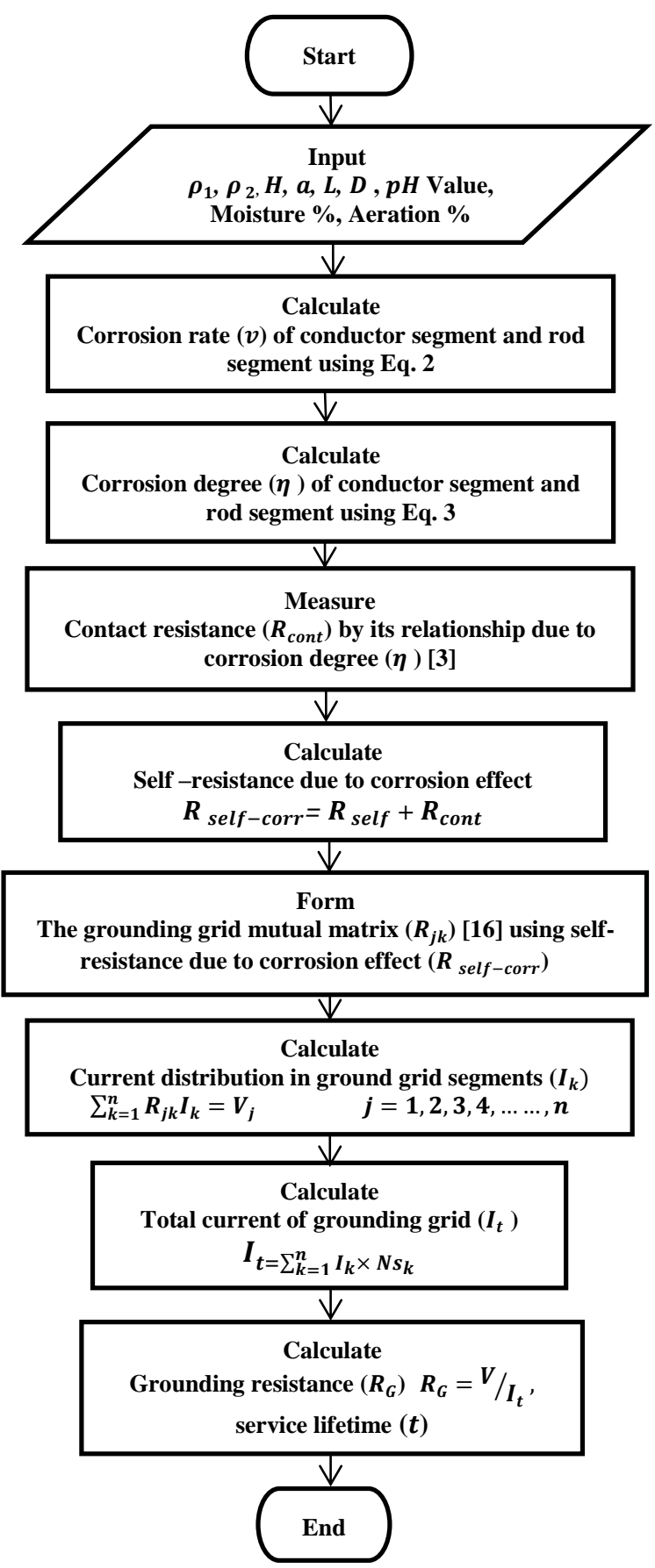

Fig. 1. Proposed technique flowchart.

In order to calculate the conductor segments corrosion rate $\left(v_{c}\right)$, In Eq. 2, the soil resistivity $(\rho)$ is equal to the upper layer 
soil resistivity $\left(\rho_{1}\right)$, however, in order to calculate the rod segments corrosion rate $\left(v_{r}\right)$ the soil resistivity $(\rho)$ is equal to the two layers soil apparent resistivity $\left(\rho_{a}\right)$.

The corrosion rates $\left(v_{c}\right)$ and $\left(v_{r}\right)$ are related to the soil condition and the material of the grounding grid. The material of grounding grid is known and certain in the process of initial design. In some industrial cases, the soil conditions may occur constantly change and the annual average corrosion rate $\left(v_{a}\right)$ may change constantly and can be measured or estimated at a certain year [3].

Fig. 1 shows the step by step flowchart used in calculations of corrosion rate, grid resistance, and grid distribution current according to the proposed technique.

The corrosion degree $(\eta)$ of the grounding grid segments is a function of the corrosion rate $(v)$ and the time $(t)$ that the grounding grid has been buried according to Eq. 3 [3]:

$$
\eta=\eta(v, t)
$$

The mutual ground resistance $\left(R_{j k}\right)$ is defined as the ratio of the earth potential over the $j_{\text {th }}$ segment when it is thought as disconnected from the grid to the ground current flowing through the $k_{t h}$ segment. The self-ground resistance of the $j_{t h}$ segment of the grounding grid according to corrosion effect $\left(R_{\text {self-corr }}\right)$ can be divided into two parts as given in Eq. 4 :

$$
R_{\text {self-corr }}=R_{\text {self-ideal }}+R_{\text {cont }}
$$

Where, $\left(R_{\text {self-ideal }}\right)$ is the ideal self-ground resistance of the $j_{\text {th }}$ segment to the remote earth, which is determined by the $(x, y, z)$ coordinates of the grounding grid segments, and $\left(R_{\text {cont }}\right)$ is the contact resistance between the $j_{t h}$ segment and the soil.

When the assessed grounding grid is in good condition, the value of $\left(R_{\text {cont }}\right)$ is small and can be assumed to be zero. That is the reason why the previous grounding grid evaluation methods ignore it [3]. However, with the service time, the value of the contact resistance $\left(R_{\text {cont }}\right)$ between the grounding grid segments and the soil will become larger. When the contact resistance $\left(R_{\text {cont }}\right)$ is large enough, it cannot be ignored.

In order to determine the relationship between contact resistance of the grounding grid segment $\left(R_{\text {cont }}\right)$ and its corrosion degree $(\eta)$, the contact resistances of specified grounding grid segment under different corrosion degrees should be measured.

An experimental study is presented in this paper to indicate the relationship between the contact resistances $\left(R_{\text {cont }}\right)$ and corrosion degree $(\eta)$ of the grounding grid segment in low resistivity condition.

\section{EXPERIMENTAL SETUP}

The components of the experimental setup are:

1. Electrolytic tank, which simulates the homogenous ground with, dimensions $50 \mathrm{~cm}$ long, $50 \mathrm{~cm}$ wide, $50 \mathrm{~cm}$ high filled by pure water with resistivity $\left(\rho_{w}\right)$ of $25 \Omega-m$., as shown in Fig. 2.

2. Two galvanized steel conductor segments, which simulate the grounding rod material with the dimension of $29 \mathrm{~cm}$ long, $5 \mathrm{~cm}$ width and $10 \mathrm{~mm}$ thickness with a density of $8.75 \mathrm{gm} / \mathrm{cm}^{3}$, as shown in Fig. 2.

3. Zinc conductor bar with, dimensions of $29 \mathrm{~cm}$ long, $5 \mathrm{~cm}$ width and $10 \mathrm{~mm}$ thickness with a density of $7.14 \mathrm{gm} / \mathrm{cm}^{3}$.

4. DC power supply with varied values from zero to 180 Volt.

5. AC power supply with varied values from zero to 220 Volt.

6. Measuring devices.

7. Copper conducting wires.

The pure water resistance and resistivity are measured by using voltmeter and ammeter method.

The corrosion of grounding conductor segment that needs to be measured is accelerated through connecting an external DC power supply as shown in Figs. 2,3, the conductor rod or segment $(A)$ is connected with the positive port of the external DC power supply, forming a loop with the negative port of the supply to the electrolytic tank with pure water. Electrons in the conductor segment are attracted by the external power. The chemical reactions (like $\mathrm{Fe} \rightarrow \mathrm{Fe}^{2+}+2 e^{-}$) occurs in the surface of conductor rod or segment (A). The metal elements in the surface of rod or segment (A) lose electrons and become the metal positive ions. The metal positive ions deprived of electrons react with the negative ions in water, such as $\mathrm{OH}^{-}$, on the surface of the conductor segment, and forming the metal oxide covering the surface of the conductor segment eventually under the effect of oxygen in the water that simulates the soil moisture content.

The process of the DC accelerated corrosion is similar to that of natural corrosion, except that the corrosion rate is speeded up.

The conductor rod or segment (B) is the control group and will be compared with the conductor (A). The two rods are buried in the same electrolytic tank with pure water $(\rho=25 \Omega$. $\mathrm{m})$ with the same size and steel material. According to Faraday's theory, the DC current flows into the water between the rods (A) and (B). The interference is illustrated in Fig. 4, the rod or segment (A) is in accelerated corrosion by the DC source that is injected into the water through the rod (A). The potential of the rod or segment $(\mathrm{B})$ is greater than the potential 
of water at the position $(p)$, and smaller than the potential of water at the position $(q)$, as shown in Fig.4. As a result, the DC stray current flows into the rod (B) at the position $(q)$ and flows from the rod or segment (B) at the position $(p)$. The DC stray current flowing from the rod or segment (B) will accelerate the corrosion of rod or segment (B). To protect it from this corrosion, conductor (B) is connected with a zinc bar.

According to the Faraday's law of electrolysis, the corrosion

D.C.

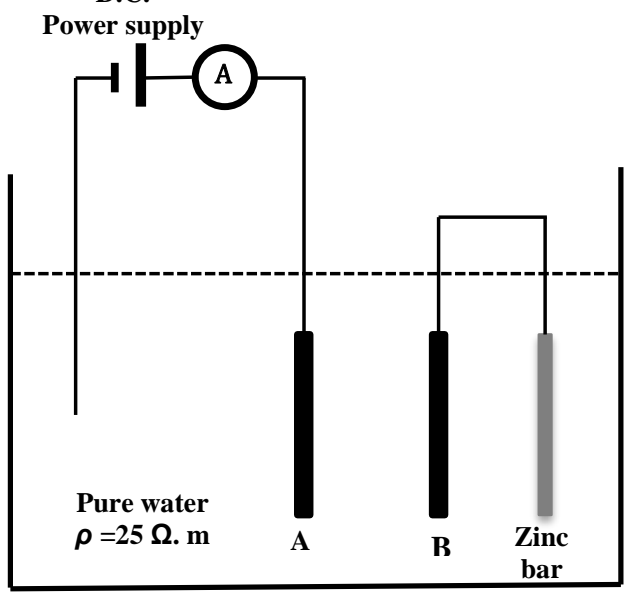

Electrolytic tank

Fig. 2. DC Corrosion acceleration scheme

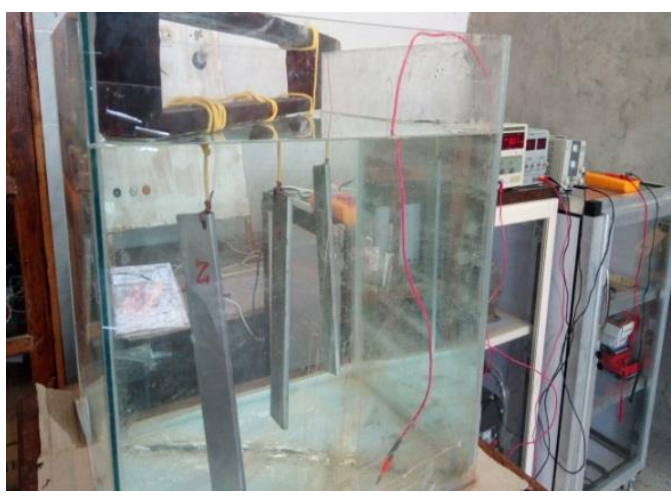

Fig. 3. The electrolytic tank with pure water $(\rho=25 \Omega$. m), steel and zinc segments.

degree of the conductor segment can be calculated using Eq. 5. [3].

$$
m=\left(\frac{Q}{F}\right) \times\left(\frac{M}{Z}\right)
$$

Where, $(m)$ is the mass of the substance liberated at the measured conductor segment in grams. $(Q)$ is the total electric charge passed through the substance. $F=96485 \mathrm{C} / \mathrm{mol}$ is the Faraday constant. $(M)$ is the molar mass of the substance. $(Z)$ is the number of electrons transferred per ion.
For Faraday's law, $(M),(F)$, and $(Z)$ are constants, the larger the value of $(Q)$, the larger $(m)$ will be. The corrosion degree $(\eta)$ is defined as the corrosion depth of conductor segment below the surface in mm or mils (mil-inch).

The corrosion degree can be expressed as [3]:

$$
\eta=m /\left(\rho_{s} \times A_{s}\right)
$$

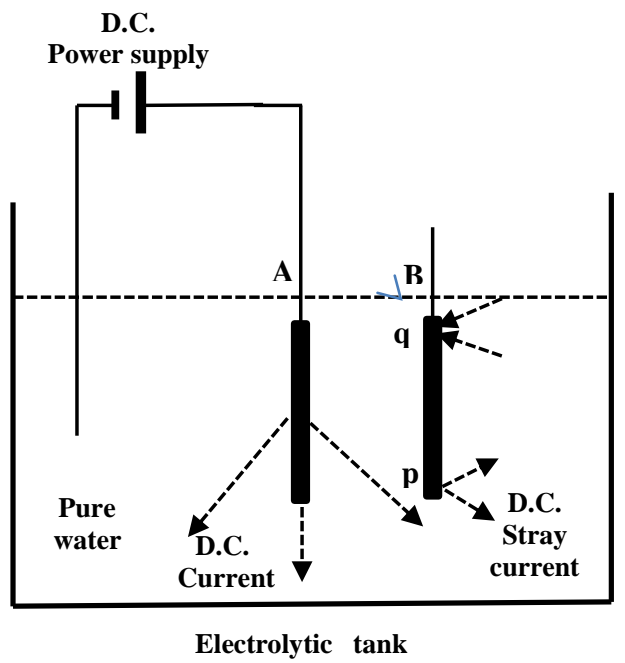

Fig. 4. The interference of segment (B) without zinc bar protection.

Where, $\left(\rho_{s}\right)$ is the density of conductor material in $\mathrm{g} / \mathrm{mm}^{3}$. $\left(A_{s}\right)$ is the surface area of the measured conductor segment in $\mathrm{mm}^{2}$. The total electric charge $(Q)$ is determined by the current flowing through the loop and the time. So the corrosion degree $(\eta)$ can be controlled by the current flowing in the loop and the flow current time.

Under a certain corrosion degree $(\eta)$, the increase of selfgrounding resistance of the conductor rod can be measured using the circuit arrangement given in Fig.4., the rod or segment (B) is disconnected to the Zinc electrode when the corrosion acceleration is interrupted and the measurement is conducted.

The self-ground resistance $\left(R_{B}\right)$ of rod or segment $(\mathrm{B})$ is equal to its ideal self-ground resistance $\left(R_{\text {sideal }}\right)$ without contact resistance as given in Eq. 7:

$$
R_{B}=R_{\text {sideal }}
$$

However, the self-ground resistance $\left(R_{A}\right)$ of rod or segment (A) is equal to the sum of the ideal self-ground resistance $\left(R_{\text {sideal }}\right)$ with contact resistance $\left(R_{\text {cont }}\right)$ as shown in Eq. 8:

$$
R_{A}=R_{\text {sideal }}+R_{\text {cont }}
$$

Then the contact resistance $\left(R_{\text {cont }}\right)$ can be calculated using Eq. 9: 


$$
R_{\text {cont }}=R_{A}-R_{B}
$$

To illustrate how the scheme is proposed to work, a set of data based on reasonable assumptions is given in table I.

A.C.

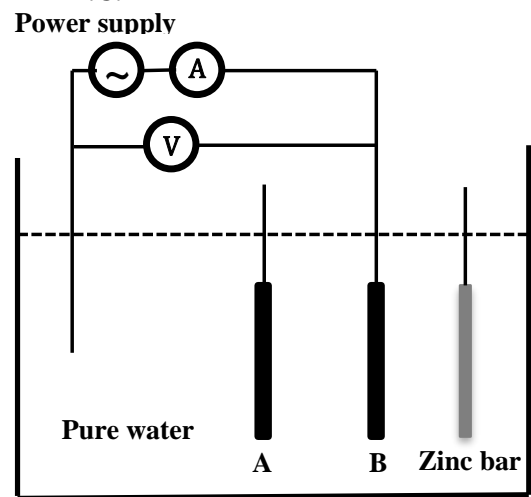

Electrolytic tank

(a)

A.C.

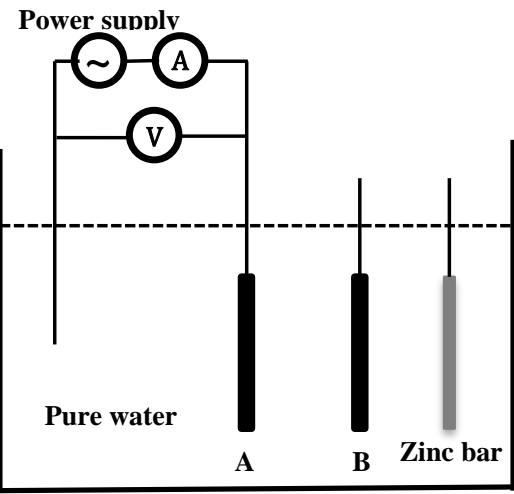

Electrolytic tank

(b)

Fig. 5. Measurement of the increase of self-ground resistance ( $\left.R_{\text {cont }}\right)$ in $(\Omega)$ schemes (a) $R_{B}$ (b) $R_{A}$.

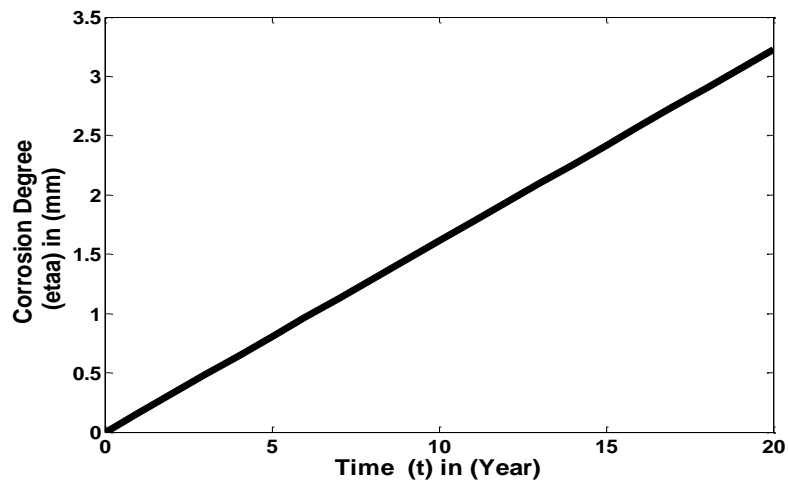

Fig. 6. Corrosion degree $(\eta)$ in $(\mathrm{mm})$ and time $(t)$ in (year) relationship.
TABLE I. Corrosion degree $(\eta)$ in $(\mathrm{mm})$ and contact resistance $\left(R_{\text {cont }}\right)$ in $(\Omega)$

\begin{tabular}{ccc} 
Time $(t)$ in & at $\left(\rho_{w}=25 \Omega . m\right)$ \\
$($ Year $)$ & $\begin{array}{c}\text { Corrosion Degree } \\
(\eta) \text { in }(\mathrm{mm})\end{array}$ & $\begin{array}{c}\text { Contact } \\
\text { Resistance }\left(R_{\text {cont }}\right) \\
\text { in }(\Omega)\end{array}$ \\
\hline 0 & 0 & 0.16 \\
1 & 0.161 & 0.25 \\
2 & 0.322 & 0.38 \\
3 & 0.483 & 0.59 \\
4 & 0.645 & 0.90 \\
5 & 0.806 & 1.38 \\
6 & 0.967 & 2.12 \\
7 & 1.128 & 3.25 \\
8 & 1.290 & 4.97 \\
9 & 1.451 & 7.62 \\
10 & 1.612 & 11.67 \\
11 & 1.774 & 17.87 \\
12 & 1.935 & 27.36 \\
13 & 2.096 & 41.90 \\
14 & 2.257 & 64.17 \\
15 & 2.419 & 98.26 \\
16 & 2.580 & 150.46 \\
17 & 2.741 & 230.40 \\
18 & 2.902 & 352.80 \\
19 & 3.064 & 540.22 \\
20 & 3.225 & 827.22 \\
\hline
\end{tabular}

The results, which have been indicated in table I, can be expressed as an empirical correlation as given in Eq. 10:

$$
R_{\text {cont }}=C_{1} \times e^{C_{2} \times \eta}
$$

Where $\left(C_{1}\right)$ and $\left(C_{2}\right)$ are constants, $C_{1}=0.164697, C_{2}=$ 2.64205 .

Fig. 6 shows the corrosion degree $(\eta)$ as a function of time $(t)$.

The empirical correlation in Eq. 10 indicates that the contact resistance $\left(R_{\text {cont }}\right)$ increases with the increase of galvanized steel corrosion degree $(\eta)$. The relation is an exponential function with a small curve slope at low corrosion degree values and with a steep curve slope at high corrosion degree values as shown in Fig. 7.

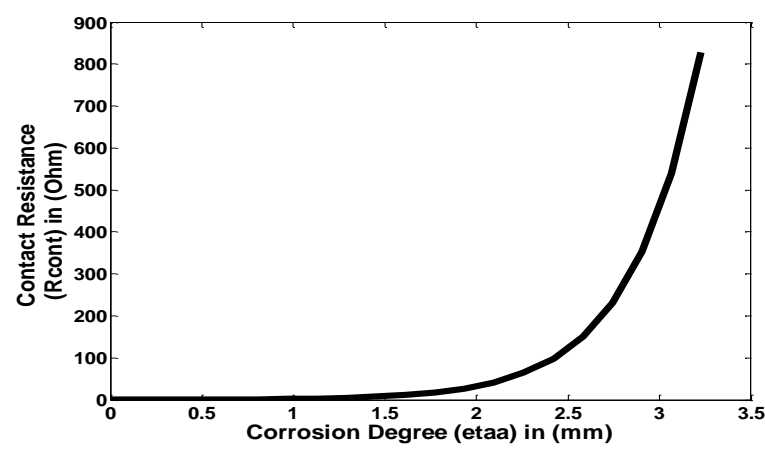

Fig. 7. Relationship between corrosion degree $(\eta)$ in $(\mathrm{mm})$ and contact 
resistance $\left(R_{\text {cont }}\right)$ in $(\Omega)$.

\section{GROUNDING SYSTEM RESISTANCE INCLUDING CORROSION EFFECT}

The total grounding grid mutual resistance matrix $\left(R_{j k}\right)$ of grounding system has contained both segments self-resistance $\left(R_{\text {self }}\right)$ and mutual resistances $\left(R_{\text {mutual }}\right)$ between the grounding grid segments and each other.

Since, the contact resistance $\left(R_{\text {cont }}\right)$ has affected only the grounding grid self-resistance $\left(R_{\text {self }}\right)$ without any effect on grounding grid mutual resistances $\left(R_{\text {mutual }}\right)$ [3], the ideal total grounding grid mutual resistance matrix $\left(R_{\text {ideal }}\right)$ is depend only on the soil resistivity $(\rho)$, the $(x, y, z)$ coordinates for each segment and the shape of the grounding grid [8].

$$
R_{\text {ideal }}=\left[\begin{array}{llll}
r_{11} & r_{12} & \cdots & r_{1 n} \\
r_{21} & r_{22} & \cdots & r_{2 n} \\
\vdots & \vdots & r & \vdots \\
r_{n 1} & r_{n 2} & \cdots & r_{n n}
\end{array}\right]
$$

However, the effect of contact resistance $\left(R_{\text {cont }}\right)$ on ideal self-resistance $\left(R_{\text {sideal }}\right)$ of the total grounding grid mutual resistance matrix $\left(R_{\text {corr }}\right)$ will be:

$$
R_{\text {corr }}=R_{\text {sideal }}+R_{\text {cont }}
$$

$$
R_{\text {corr }}=\left[\begin{array}{cccc}
r_{11} & r_{12} & \cdots & r_{1 n} \\
r_{21} & r_{22} & \cdots & r_{2 n} \\
\vdots & \vdots & r \cdot & \vdots \\
r_{n 1} & r_{n 2} & \cdots & r_{n n}
\end{array}\right]+\left[\begin{array}{cccc}
R_{\text {cont }} & 0 & \cdots & 0 \\
0 & R_{\text {cont }} & 0 & 0 \\
\vdots & \vdots & R_{\text {cont }} & \vdots \\
0 & 0 & \cdots & R_{\text {cont }}
\end{array}\right]
$$

Since the corrosion degree $(\eta)$ has been changed constantly [3], then at the certain year $(t)$, the corrosion degree of the conductor segment $(\eta)$ can be calculated. The contact resistance $\left(R_{\text {cont }}\right)$ at a certain corrosion degree $(\eta)$ can be measured using the method proposed in this paper. So, the total grounding grid mutual resistance matrix due to corrosion effect at any year $(t)\left(R_{\text {corr }}(t)\right)$ of grounding grid service lifetime can be obtained by Eq. 14:

$$
R_{\text {corr }}(t)=\left[\begin{array}{cccc}
r_{11} & r_{12} & \cdots & r_{1 n} \\
r_{21} & r_{22} & \cdots & r_{2 n} \\
\vdots & \vdots & r & \vdots \\
r_{n 1} & r_{n 2} & \cdots & r_{n n}
\end{array}\right]+\left[\begin{array}{cccc}
R_{\operatorname{cont}(t)} & 0 & \cdots & 0 \\
0 & R_{\operatorname{cont}(t)} & 0 & 0 \\
\vdots & \vdots & R_{\operatorname{cont}(t)} & \vdots \\
0 & 0 & \cdots & R_{\operatorname{cont}(t)}
\end{array}\right]
$$

Since the total mutual resistance due to corrosion effect at any year of service lifetime $\left(R_{\text {corr }}(t)\right)$ has been indicated using Eq. 14, the current distribution in each segment of the grounding grid $\left(I_{k-c o r r}\right)$ and ground resistance to ground $\left(R_{G-c o r r}\right)$ due to corrosion effect can be calculated.

The grounding grid current distribution of each segment with corrosion effect $\left(I_{k-\text { corr }}\right)$ can be obtained by dividing the voltages applied on each segment $(V)$, which assumed constant, by the total grounding grid mutual resistance matrix due to corrosion effect $\left(R_{\text {corr }}\right)$ as given in Eq. 15 [16]:

$$
I_{k-\text { corr }}=\frac{V}{R_{\text {corr }}}
$$

Then the total current of grounding grid due to corrosion effect $\left(I_{t-\text { corr }}\right)$ can be calculated using Eq. 16 [16]:

$$
I_{t-\operatorname{corr}}=\sum_{k=1}^{n} \quad I_{k-\operatorname{corr}} \times N_{s_{k}}
$$

Where:

$I_{t-c o r r}$ : is the total current of the grounding grid due to corrosion effect in (A)

$I_{k-c o r r}:$ is the current of each segment due to corrosion effect in $(\mathrm{A})$

$N_{s k}:$ is the number of segments of the same segment current type

$n: \quad$ is the number of segment current types

Therefore, the grounding grid resistance due to corrosion effect $\left(R_{G-\text { corr }}\right)$ is calculated using Eq.17. [16]:

$$
R_{G-\mathrm{corr}}=\frac{V}{I_{t-c o r r}}
$$

Where:

$$
\begin{array}{ll}
R_{G-\text { corr }}: & \text { is the grounding resistance to the ground due to } \\
& \text { corrosion effect in }(\Omega) \\
V: \quad & \text { is the list of voltages applied on the }(n) \\
& \text { segments in }(\mathrm{V})
\end{array}
$$

In order to increase the flexibility of the calculations of this study, per unit system has been used by taking:

$$
\begin{aligned}
& K V A_{\text {Base }}=100 \mathrm{KVA}, K V_{\text {Base }}=10 \mathrm{KV}, \\
& I_{\text {Base }}=K V A_{\text {Base }} / K V_{\text {Base }},
\end{aligned}
$$


$R_{\text {Base }}=\left[\left(K V_{\text {Base }}\right)^{2} \times 1000\right] / K V A_{\text {Base }}$

Two layers soil model is assumed with upper layer soil resistivity $\rho_{1}=33 \Omega . \mathrm{m}$ and lower layer soil resistivity $\rho_{2}=19$ $\Omega . \mathrm{m}$, and apparent soil resistivity $\rho_{a}=24.9552 \cong 25 \Omega . \mathrm{m}$ which has been calculated using IEEE standard 80-2000 [9].

The assumed system parameters are considered as:

Soil $\mathrm{pH}$ value $=7$ (neutral soil), Soil moisture $(\%)=30$, Soil aeration $(\%)=15$, Length of each segment $L=8 \mathrm{~m}$ (conductors and rods), Depth of burial of grounding grid $H=0.5 \mathrm{~m}$, The top layer thickness $D=5 \mathrm{~m}$. Conductor radius $a=0.007 \mathrm{~m}$ (4/0 wire), list of voltages applied on the $n$ segments $V_{p . u .}=1.5$ p.u. (assumed constant to all grid segments).

\section{A. Grounding Grid without Vertical Rods}

By dividing the grounding grid without vertical rods into separated conductor segments. The segments which located near to the center of the grounding grid, have the same current, similarly, the segments, which located far from the center of the grounding grid have the same current also.

The current of the grounding grid segments decreases with time due to corrosion effect.

In the grounding grid $(3 \times 3)$, with 9 meshes and 24 conductor segments, there are four different current types. The currents passing through each segment of grounding grid $(3 \times 3)$ in (p.u.) at different buried times are shown in Fig. 8.

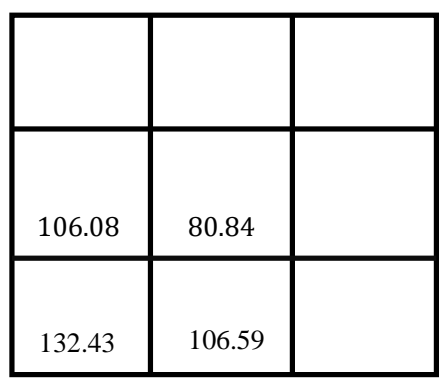

(a)

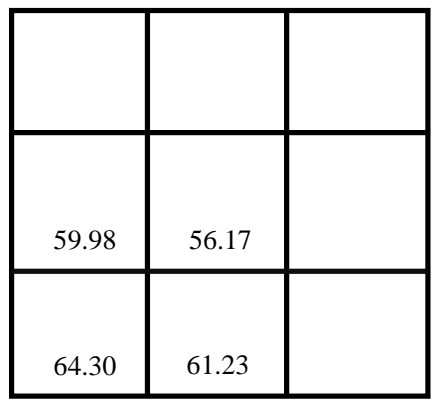

(b)

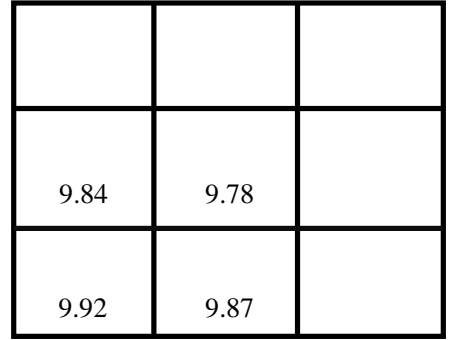

(c)

Fig. 8. Grounding grid $(3 \times 3)$ current distribution in (p.u.) at buried time (a) $t=0$ year (b) $t=10$ years (c) $t=20$ years

TABLE II. Current distribution of different shapes steel grounding grids without vertical rods along service lifetime

\begin{tabular}{|c|c|c|c|c|c|}
\hline \multirow[t]{2}{*}{$\begin{array}{l}\text { G. G. } \\
\text { Lifetime } \\
(t) \text { in } \\
\text { (Year) }\end{array}$} & \multirow{2}{*}{$\begin{array}{l}\text { G. G. }(1 \times 1) \\
\text { Each } \\
\text { Segment } \\
\text { Current }\left(I_{k}\right) \\
\text { in (p.u.) }\end{array}$} & \multicolumn{2}{|c|}{$\begin{array}{c}\text { G. G. }(2 \times 2) \\
\text { Each Segment } \\
\text { Current }\left(I_{k}\right) \text { in (p.u.) }\end{array}$} & \multicolumn{2}{|c|}{$\begin{array}{l}\text { G. G. }(3 \times 3) \\
\text { Each Segment } \\
\text { Current }\left(I_{k}\right) \\
\text { in (p.u.) }\end{array}$} \\
\hline & & $\begin{array}{c}\text { Near } \\
\text { Center }\end{array}$ & $\begin{array}{c}\text { Far } \\
\text { Center }\end{array}$ & Near Center & $\begin{array}{c}\text { Far } \\
\text { Center }\end{array}$ \\
\hline 0 & 229.91 & 146.86 & 150.40 & 80.84 & 132.43 \\
\hline Initial & & & & 106.08 & 106.59 \\
\hline 1 & 226.91 & 145.69 & 149.08 & $\begin{array}{c}80.84 \\
105.42\end{array}$ & $\begin{array}{l}131.13 \\
106.15\end{array}$ \\
\hline 2 & 222.49 & 143.94 & 147.12 & $\begin{array}{c}80.80 \\
104.42\end{array}$ & $\begin{array}{l}129.22 \\
105.46\end{array}$ \\
\hline 3 & 216.08 & 141.34 & 144.24 & $\begin{array}{c}80.69 \\
102.96\end{array}$ & $\begin{array}{l}126.45 \\
104.37\end{array}$ \\
\hline 4 & 206.99 & 137.52 & 140.07 & $\begin{array}{c}80.39 \\
100.82\end{array}$ & $\begin{array}{l}122.52 \\
102.65\end{array}$ \\
\hline 5 & 194.53 & 132.05 & 134.18 & $\begin{array}{c}79.69 \\
97.762\end{array}$ & $\begin{array}{l}117.10 \\
99.983\end{array}$ \\
\hline 6 & 178.19 & 124.45 & 126.12 & $\begin{array}{l}78.25 \\
93.46\end{array}$ & $\begin{array}{c}109.92 \\
95.94\end{array}$ \\
\hline 7 & 157.97 & 114.36 & 115.59 & $\begin{array}{l}75.58 \\
87.63\end{array}$ & $\begin{array}{c}100.82 \\
90.11\end{array}$ \\
\hline 8 & 134.69 & 101.73 & 102.57 & $\begin{array}{l}71.14 \\
80.03\end{array}$ & $\begin{array}{l}89.88 \\
82.26\end{array}$ \\
\hline 9 & 110.00 & 87.04 & 87.57 & $\begin{array}{l}64.62 \\
70.68\end{array}$ & $\begin{array}{l}77.48 \\
72.45\end{array}$ \\
\hline 10 & 85.99 & 71.32 & 71.62 & $\begin{array}{l}56.17 \\
59.98\end{array}$ & $\begin{array}{l}64.30 \\
61.23\end{array}$ \\
\hline 11 & 64.53 & 55.91 & 56.08 & $\begin{array}{l}46.50 \\
48.72\end{array}$ & $\begin{array}{l}51.26 \\
49.51\end{array}$ \\
\hline 12 & 46.75 & 42.06 & 42.15 & $\begin{array}{l}36.67 \\
37.87\end{array}$ & $\begin{array}{l}39.26 \\
38.33\end{array}$ \\
\hline 13 & 39.36 & 35.98 & 36.04 & $\begin{array}{l}32.01 \\
32.88\end{array}$ & $\begin{array}{l}33.88 \\
33.21\end{array}$ \\
\hline 14 & 32.93 & 30.53 & 30.58 & $\begin{array}{l}27.65 \\
28.27\end{array}$ & $\begin{array}{l}28.98 \\
28.51\end{array}$ \\
\hline 15 & 27.41 & 25.73 & 25.76 & $\begin{array}{l}23.67 \\
24.10\end{array}$ & $\begin{array}{l}24.60 \\
24.28\end{array}$ \\
\hline 16 & 22.70 & 21.54 & 21.56 & $\begin{array}{l}20.09 \\
20.39\end{array}$ & $\begin{array}{l}20.74 \\
20.51\end{array}$ \\
\hline 17 & 18.74 & 17.94 & 17.95 & $\begin{array}{l}16.93 \\
17.13\end{array}$ & $\begin{array}{l}17.37 \\
17.22\end{array}$ \\
\hline 18 & 15.41 & 14.87 & 14.88 & $\begin{array}{l}14.17 \\
14.31\end{array}$ & $\begin{array}{l}14.48 \\
14.37\end{array}$ \\
\hline 19 & 12.64 & 12.27 & 12.28 & $\begin{array}{l}11.80 \\
11.89\end{array}$ & $\begin{array}{l}12.00 \\
11.93\end{array}$ \\
\hline 20 & 10.35 & 10.10 & 10.10 & $\begin{array}{l}9.78 \\
9.84\end{array}$ & $\begin{array}{l}9.92 \\
9.87\end{array}$ \\
\hline
\end{tabular}


The current distribution of the galvanized steel grounding grid without vertical rods with different shapes under the effect of corrosion along the lifetime is evaluated using Eq.15 and listed in Table II.

\section{B. Grounding grid with vertical rods}

The grounding grids with a number of vertical rods are divided into conductor and rod separated segments. The current distribution of the grounding grid segments decreases with time according to corrosion effect.

In the grounding grid $(3 \times 3)$, with nine meshes and 24 conductor segments and 16-rod segments, there are six types of the current passing through the conductor and rod segments of the grounding grid.

The currents which pass through each segment of grounding grid $(3 \times 3)$ with 16 rods at different buried times of the grounding grid lifetime are shown in Fig. 9.

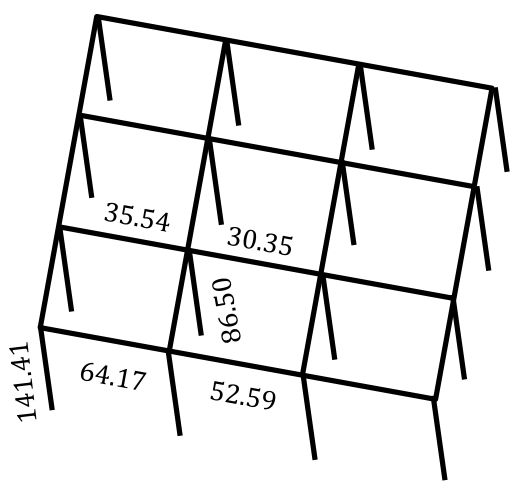

(a)

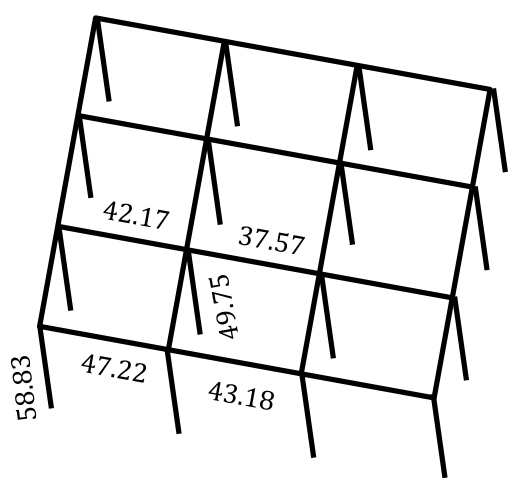

(b)

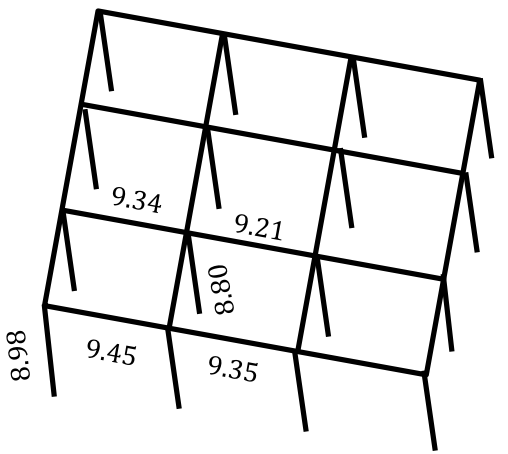

(c)

Fig. 9. Grounding grid $(3 \times 3)$ with 16 vertical rods current distribution in (p.u.) at buried time

(a) $t=0$ year (b) $t=10$ years (c) $t=20$ years

The current distribution of the galvanized steel grounding grid with vertical rods with different shapes under the effect of corrosion along the lifetime is evaluated using Eq.15 and listed in Table III.

It may be noticed from Table II and Table III, that the grounding grid current distribution which pass through each type of the segment current types has been decreased by the increase of the service buried time $(t)$.

Further, it may be remained that, the rod segments current is decreased rapidly more than the conductor segments current this may be due to the effect of the two-layer soil resistivity difference.

Moreover, it may be remained that, the currents which pass through the far segments from the grounding grid center are higher than that pass through the near segments to the grounding grid center of different shapes of grounding grids, this may relied to different buried times.

\section{COMPARISON BETWEEN GROUNDING GRIDS WITH AND WITHOUT VERTICAL RODS CURRENT DISTRIBUTION ACCORDING TO CORROSION EFFECT}

As shown in Fig. 10, and Fig. 11, the corrosion degree $(\eta)$ of the grounding grid segments, conductors and/or rods, is increased by a linear function, however, the contact resistance of the grounding grid segments $\left(R_{\text {cont }}\right)$ is increased by an exponential function due to the increase of service lifetime of the ground grid $(t)$.

The corrosion degree of each rod segment $\left(\eta_{r}\right)$ is higher than the corrosion degree of each conductor segment $\left(\eta_{c}\right)$ of grounding grid along the lifetime of different shapes grounding grids because of the difference of the two layers soil resistivity. 
TABLE III. Current distribution through different shapes of steel grounding

\begin{tabular}{|c|c|c|c|c|c|c|}
\hline \multirow[t]{2}{*}{$\begin{array}{l}\text { G. G. } \\
\text { Lifetime } \\
(t) \text { in } \\
\text { (Year) }\end{array}$} & \multicolumn{2}{|c|}{$\begin{array}{c}\text { G. G. }(1 \times 1) \\
\text { with } 4 \text { Rods } \\
\text { Each Segment } \\
\text { Current }\left(I_{k}\right) \\
\text { in (p.u.) }\end{array}$} & \multicolumn{2}{|c|}{$\begin{array}{l}\text { G. G. }(2 \times 2) \\
\text { with } 9 \text { Rods } \\
\text { Each Segment } \\
\text { Current }\left(I_{k}\right) \\
\text { in (p.u.) }\end{array}$} & \multicolumn{2}{|c|}{$\begin{array}{c}\text { G. G. }(3 \times 3) \\
\text { with } 16 \text { Rods } \\
\text { Each Segment } \\
\text { Current }\left(I_{k}\right) \\
\text { in (p.u.) }\end{array}$} \\
\hline & Conductor & Rod & $\begin{array}{c}\text { Conductor } \\
\text { Far } \\
\text { Near } \\
\end{array}$ & $\begin{array}{c}\text { Rod } \\
\text { Far } \\
\text { Near }\end{array}$ & $\begin{array}{c}\text { Conductor } \\
\text { Far } \\
\text { Near } \\
\end{array}$ & $\begin{array}{c}\text { Rod } \\
\text { Far } \\
\text { Near } \\
\end{array}$ \\
\hline $\begin{array}{c}0 \\
\text { Initial }\end{array}$ & 125.22 & 197.55 & $\begin{array}{l}83.48 \\
70.48\end{array}$ & $\begin{array}{l}156.73 \\
105.92\end{array}$ & $\begin{array}{l}64.17-52.59 \\
35.54-30.35\end{array}$ & $\begin{array}{r}141.41 \\
86.50\end{array}$ \\
\hline 1 & 124.62 & 194.93 & $\begin{array}{l}83.31 \\
70.74\end{array}$ & $\begin{array}{l}154.76 \\
105.44\end{array}$ & $\begin{array}{l}64.18-52.66 \\
36.26-30.75\end{array}$ & $\begin{array}{r}139.51 \\
86.05\end{array}$ \\
\hline 2 & 123.69 & 191.08 & $\begin{array}{l}83.05 \\
71.08\end{array}$ & $\begin{array}{l}151.86 \\
104.68\end{array}$ & $\begin{array}{l}64.17-52.75 \\
37.27-31.35\end{array}$ & $\begin{array}{r}136.71 \\
85.37\end{array}$ \\
\hline 3 & 122.27 & 185.50 & $\begin{array}{l}82.61 \\
71.49\end{array}$ & $\begin{array}{l}147.67 \\
103.49\end{array}$ & $\begin{array}{l}64.12-52.86 \\
38.65-32.20\end{array}$ & $\begin{array}{r}132.70 \\
84.31\end{array}$ \\
\hline 4 & 120.07 & 177.62 & $\begin{array}{l}81.89 \\
71.88\end{array}$ & $\begin{array}{l}141.78 \\
101.62\end{array}$ & $\begin{array}{l}63.95-52.97 \\
40.42-33.36\end{array}$ & $\begin{array}{c}127.11 \\
82.69\end{array}$ \\
\hline 5 & 116.71 & 166.90 & $\begin{array}{l}80.69 \\
72.07\end{array}$ & $\begin{array}{c}133.80 \\
98.75\end{array}$ & $\begin{array}{r}63.50-52.99 \\
42.50-34.85\end{array}$ & $\begin{array}{r}119.61 \\
80.28\end{array}$ \\
\hline 6 & 111.68 & 152.98 & $\begin{array}{l}78.71 \\
71.68\end{array}$ & $\begin{array}{c}123.48 \\
94.45\end{array}$ & $\begin{array}{l}62.55-52.77 \\
44.61-36.59\end{array}$ & $\begin{array}{r}110.05 \\
76.79\end{array}$ \\
\hline 7 & 104.42 & 135.95 & $\begin{array}{l}75.52 \\
70.16\end{array}$ & $\begin{array}{c}110.88 \\
88.33\end{array}$ & $\begin{array}{l}60.74-52.04 \\
46.25-38.28\end{array}$ & $\begin{array}{l}98.59 \\
71.98\end{array}$ \\
\hline 8 & 94.60 & 116.48 & $\begin{array}{l}70.71 \\
66.91\end{array}$ & $\begin{array}{l}96.44 \\
80.16\end{array}$ & $\begin{array}{l}57.72-50.43 \\
46.75-39.43\end{array}$ & $\begin{array}{l}85.71 \\
65.75\end{array}$ \\
\hline 9 & 82.36 & 95.87 & $\begin{array}{l}64.01 \\
61.52\end{array}$ & $\begin{array}{l}80.98 \\
70.11\end{array}$ & $\begin{array}{l}53.21-47.54 \\
45.48-39.36\end{array}$ & $\begin{array}{l}72.19 \\
58.22\end{array}$ \\
\hline 10 & 68.51 & 75.68 & $\begin{array}{l}55.56 \\
54.06\end{array}$ & $\begin{array}{l}65.51 \\
58.80\end{array}$ & $\begin{array}{l}47.22-43.18 \\
42.17-37.57\end{array}$ & $\begin{array}{l}58.83 \\
49.75\end{array}$ \\
\hline 11 & 54.36 & 57.40 & $\begin{array}{l}46.02 \\
45.18\end{array}$ & $\begin{array}{l}51.01 \\
47.18\end{array}$ & $\begin{array}{l}40.11-37.48 \\
37.05-33.93\end{array}$ & $\begin{array}{l}46.38 \\
40.89\end{array}$ \\
\hline 12 & 41.26 & 41.98 & $\begin{array}{l}36.35 \\
35.90\end{array}$ & $\begin{array}{l}38.30 \\
36.25\end{array}$ & $\begin{array}{l}32.53-30.95 \\
30.80-28.88\end{array}$ & $\begin{array}{l}35.36 \\
32.27\end{array}$ \\
\hline 13 & 35.42 & 35.48 & $\begin{array}{l}31.76 \\
31.44\end{array}$ & $\begin{array}{l}32.77 \\
31.30\end{array}$ & $\begin{array}{l}28.79-27.61 \\
27.53-26.07\end{array}$ & $\begin{array}{l}30.51 \\
28.24\end{array}$ \\
\hline 14 & 30.15 & 29.79 & $\begin{array}{l}27.47 \\
27.24\end{array}$ & $\begin{array}{l}27.82 \\
26.78\end{array}$ & $\begin{array}{l}25.21-24.34 \\
24.30-23.22\end{array}$ & $\begin{array}{l}26.11 \\
24.48\end{array}$ \\
\hline 15 & 25.46 & 24.86 & $\begin{array}{l}23.53 \\
23.38\end{array}$ & $\begin{array}{l}23.45 \\
22.73\end{array}$ & $\begin{array}{l}21.85-21.22 \\
21.20-20.41\end{array}$ & $\begin{array}{l}22.19 \\
21.02\end{array}$ \\
\hline 16 & 21.36 & 20.63 & $\begin{array}{l}19.99 \\
19.88\end{array}$ & $\begin{array}{l}19.64 \\
19.14\end{array}$ & $\begin{array}{l}18.76-18.31 \\
18.30-17.74\end{array}$ & $\begin{array}{l}18.72 \\
17.91\end{array}$ \\
\hline 17 & 17.82 & 17.05 & $\begin{array}{l}16.86 \\
16.78\end{array}$ & $\begin{array}{l}16.36 \\
16.02\end{array}$ & $\begin{array}{l}15.97-15.65 \\
15.65-15.25\end{array}$ & $\begin{array}{l}15.70 \\
15.13\end{array}$ \\
\hline 18 & 14.79 & 14.03 & $\begin{array}{l}14.12 \\
14.07\end{array}$ & $\begin{array}{l}13.56 \\
13.33\end{array}$ & $\begin{array}{l}13.49-13.27 \\
13.27-12.99\end{array}$ & $\begin{array}{l}13.10 \\
12.70\end{array}$ \\
\hline 19 & 12.2253 & 11.52 & $\begin{array}{l}11.76 \\
11.73\end{array}$ & $\begin{array}{l}11.19 \\
11.03\end{array}$ & $\begin{array}{l}11.32-11.17 \\
11.17-10.98\end{array}$ & $\begin{array}{l}10.87 \\
10.60\end{array}$ \\
\hline 20 & 10.06 & 9.42 & $\begin{array}{l}9.75 \\
9.73\end{array}$ & $\begin{array}{l}9.20 \\
9.10\end{array}$ & $\begin{array}{l}9.45-9.35 \\
9.34-9.21\end{array}$ & $\begin{array}{l}8.98 \\
8.80\end{array}$ \\
\hline
\end{tabular}

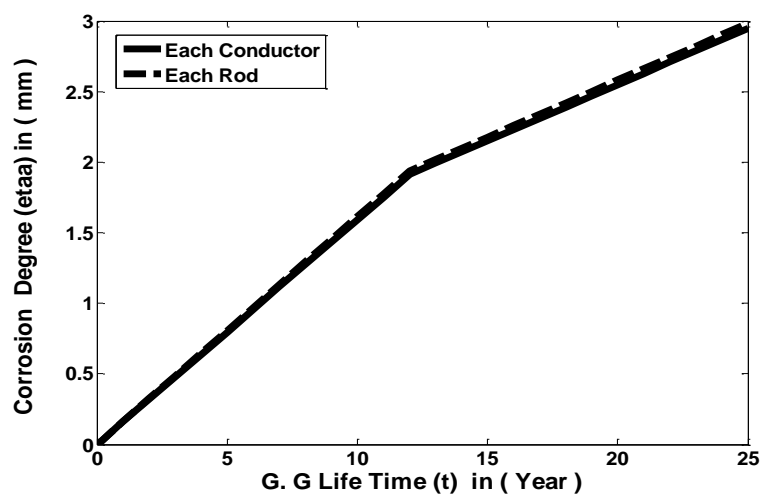

Fig. 10. Grounding grid corrosion degree $(\eta)$ in $(\mathrm{mm})$ of each segment along the service lifetime

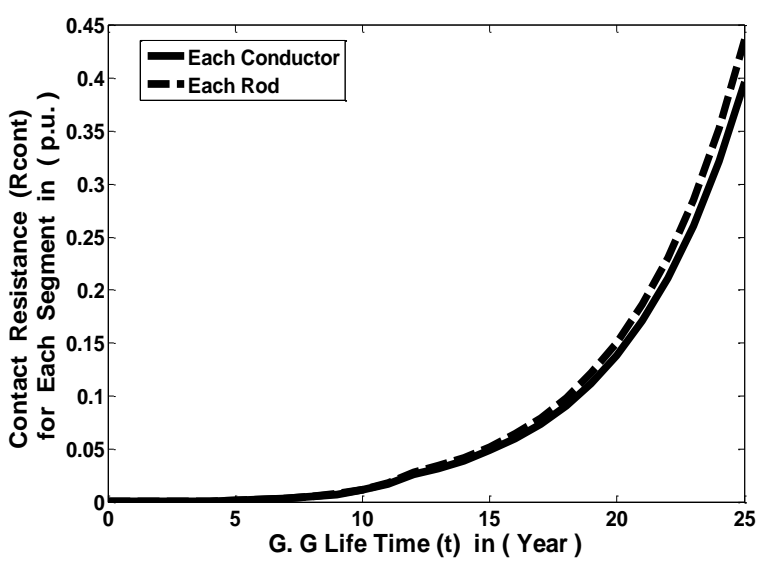

Fig. 11. Grounding grid contact resistance $\left(R_{\text {cont }}\right)$ in (p.u.) of each segment along the service lifetime

Further, it may be illustrated from Fig. 10 that the corrosion degree $(\eta)$ after the first 12 years is half of the corrosion degree within the second 12 years service lifetime of grounding grids [4], the increase of the corrosion degree $(\eta)$ curve slope after 12 years is lower than the curve slope at first 12 years lifetime.

It may be remained from Fig. 12, and Fig. 13, that the current distribution passed through each conductor and/or rod segments is decreased by the increase of each segment corrosion degree $(\eta)$ of the grounding grids by same curves slops. 


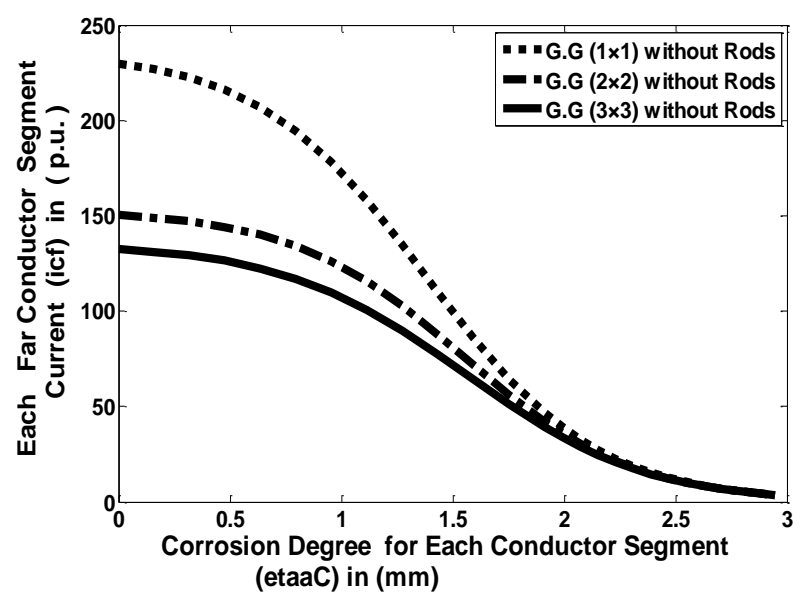

(a)

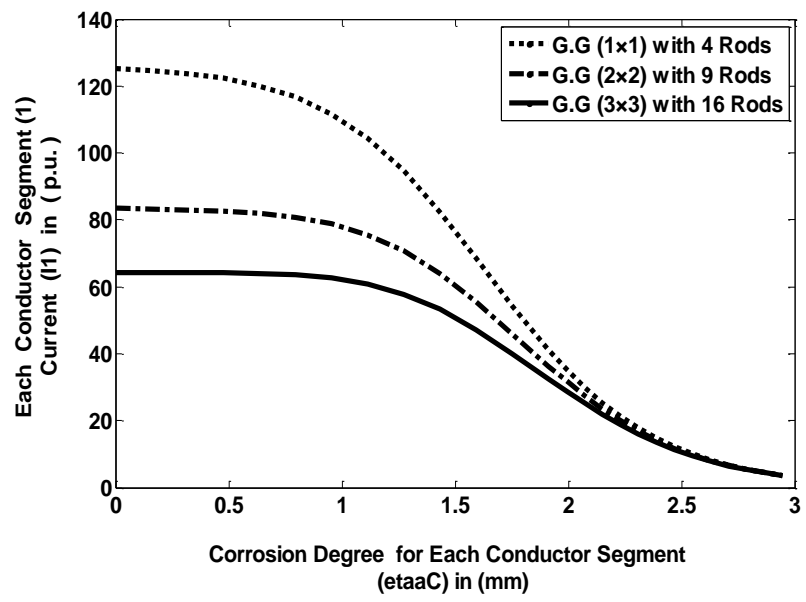

(b)

Fig. 12. Effect of conductor corrosion degree $\left(\eta_{c}\right)$ in $(\mathrm{mm})$ on far conductor segments current $\left(I_{c f}\right)$ in (p.u.) of different shapes grounding grids (a) without rods (b) with rods

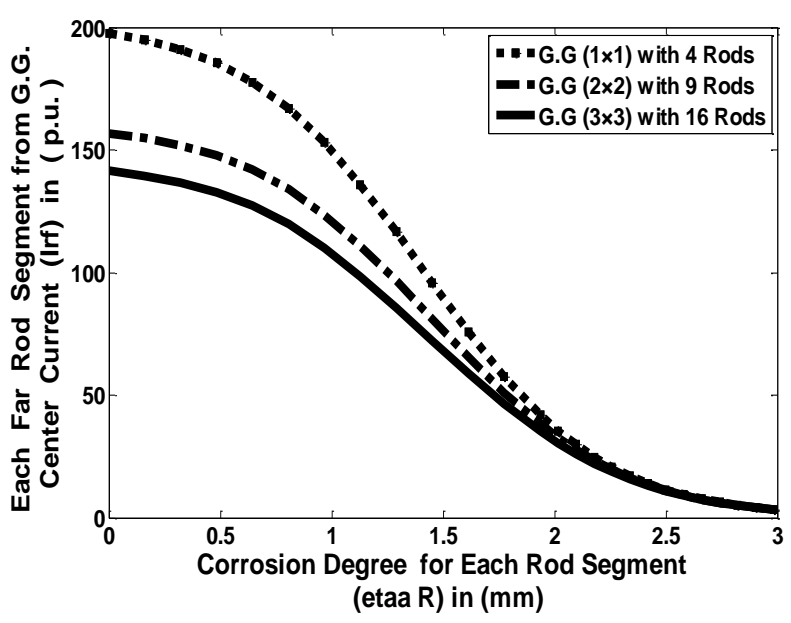

(a)

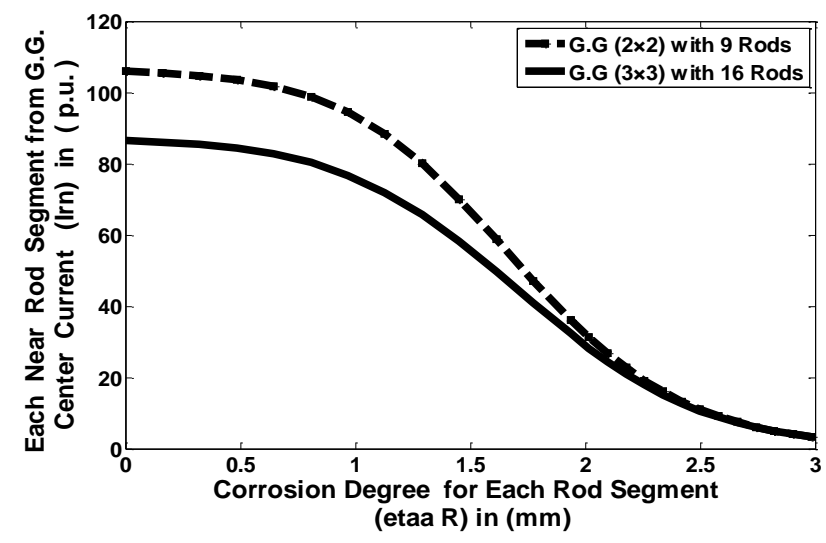

(b)

Fig. 13. Effect of rod corrosion degree $\left(\eta_{r}\right)$ in $(\mathrm{mm})$ of each rod segments current $\left(I_{r f}\right)$ in (p.u.) of different shapes grounding grids (a) far from G.G. center (b) near to G.G. center

The decrease of the ground grid segments current distribution is high in the first 12 years of the grid service lifetime, and then it is small after this period.

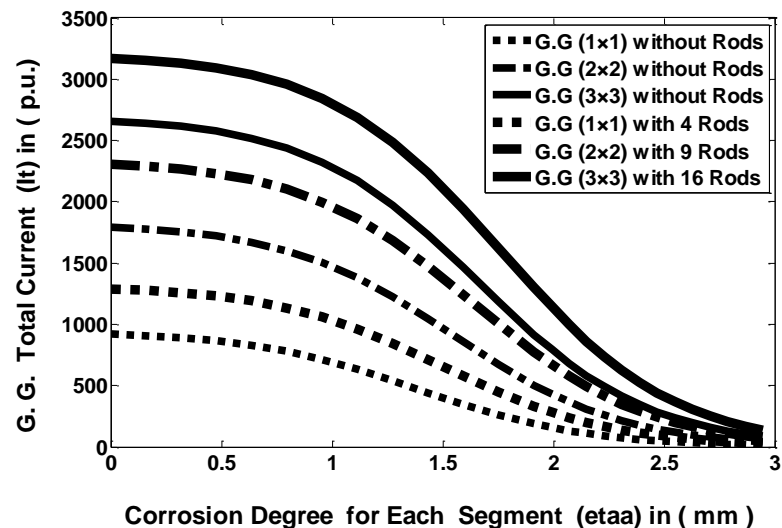

Fig. 14.. Effect of corrosion degree $(\eta)$ in $(\mathrm{mm})$ on total current $\left(I_{t}\right)$ in (p.u.) of different shapes grounding grids

Fig. 14 shows that the total current $\left(I_{t}\right)$ of the different shapes grounding grids is decreased by the increase of segments corrosion degree $(\eta)$ along the grounding grid service lifetime $(t)$.

The total current $\left(I_{t}\right)$ of the grounding grid $(1 \times 1)$ with 4 vertical rods is higher than that of the same dimensions grounding grid without vertical rods. Moreover, the same relationship has been indicated for the grounding grid $(2 \times 2)$ and $(3 \times 3)$.

The grounding grid $(3 \times 3)$ with 16 vertical rods is the highest total current $\left(I_{t}\right)$ in the same ground conditions and corrosion degrees of the studied ground grids. 


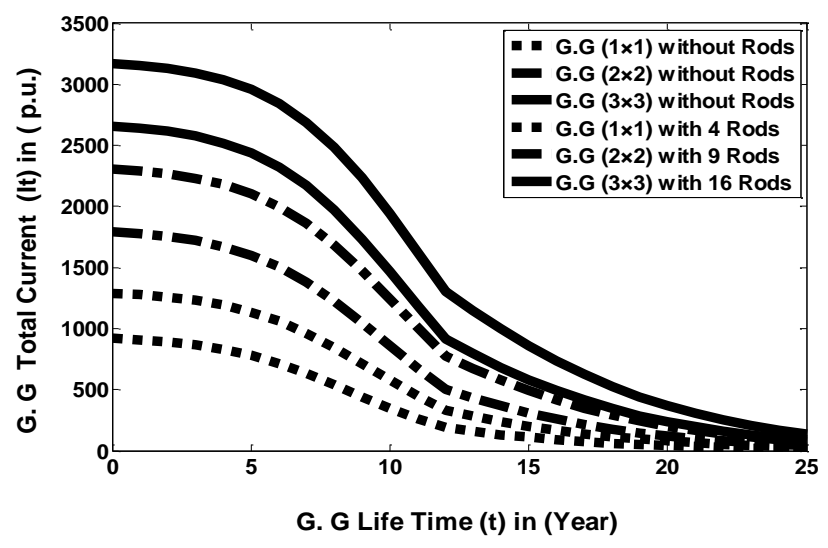

Fig. 15. Total current $\left(I_{t}\right)$ in (p.u.) of different grounding grids for the service lifetime

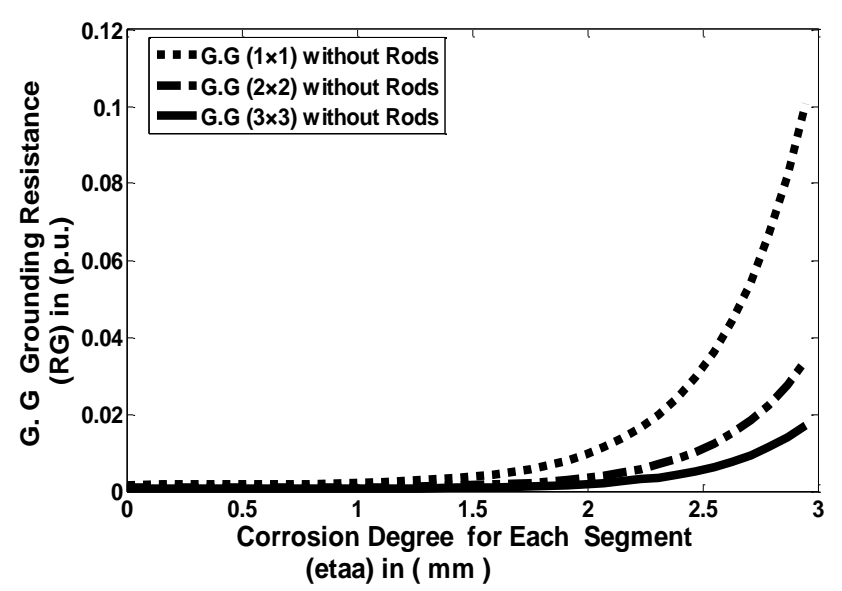

(a)

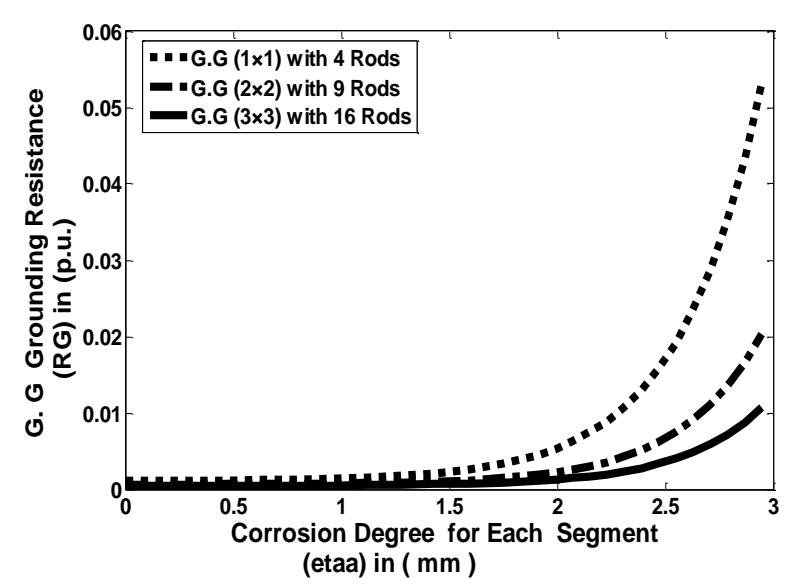

(b)

Fig. 16. Effect of corrosion degree $(\eta)$ in $(\mathrm{mm})$ on ground resistance $\left(R_{G}\right)$ in (p.u.) of different grounding grids (a) without rods (b) with rods

It may be noticed from Fig. 16 that, the resistance to ground $\left(R_{G}\right)$ of different shapes grounding grids increases by the increase of the segments corrosion degree $(\eta)$ due to the increase of the grounding grid service lifetime $(t)$.

Further, it may be illustrated from Fig.16 that, the ground resistance $\left(R_{G}\right)$ of the grounding grid $(1 \times 1)$ with 4 vertical rods is smaller than the ground resistance of the same dimensions grounding grid without vertical rods. The same trend may be remained in grounding grid $(2 \times 2)$ and $(3 \times 3)$.

The grounding grid $(3 \times 3)$ with 16 vertical rods is the smallest ground resistance $\left(R_{G}\right)$ in the same ground conditions and corrosion degrees of the studied ground grids.

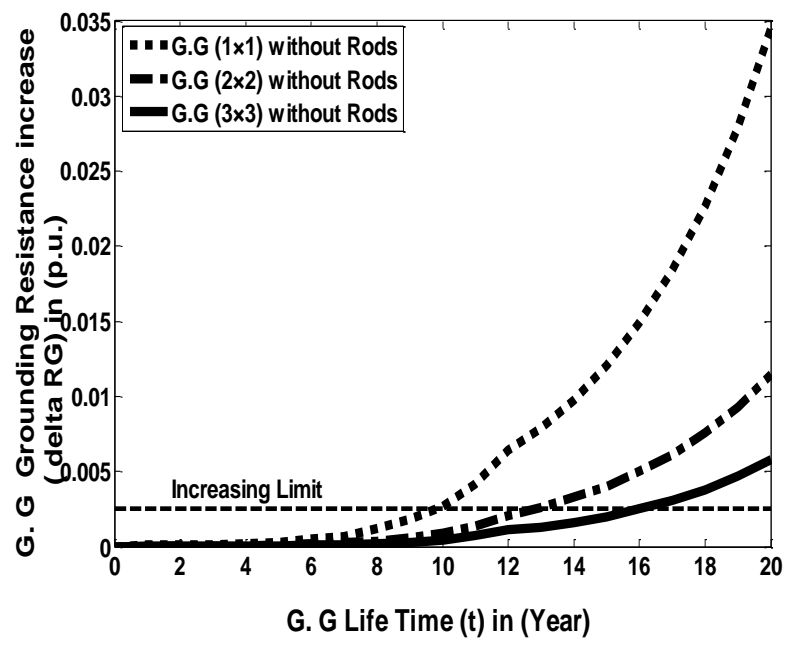

(a)

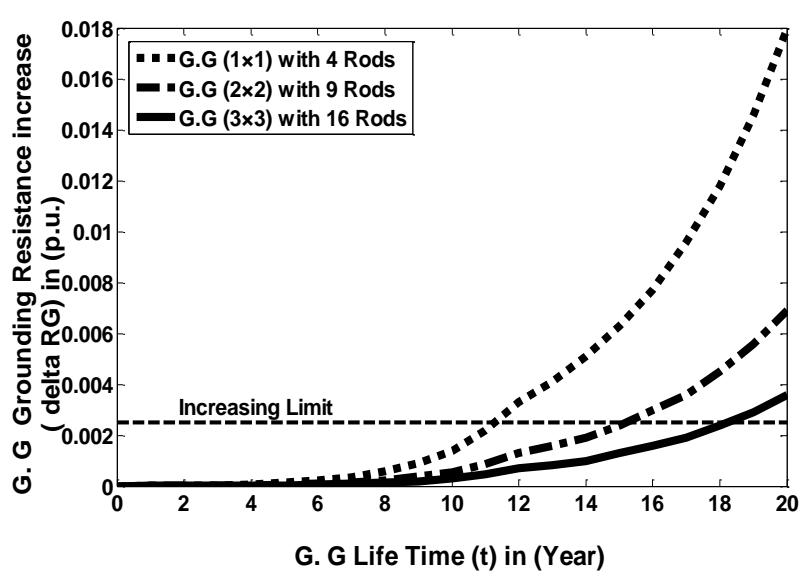

(b)

Fig. 17. Ground resistance increase $\left(\Delta R_{G}\right)$ in (p.u.) of different grounding grids (a) without rods (b) with rods

It may be remained from Fig. 17 that, the ground resistance increase $\left(\Delta R_{G}\right)$ increases along the service lifetime of different shapes grounding grids. 
The slope of the ground resistance increase $\left(\Delta R_{G}\right)$ curve is very narrow at the first 12-year of the service lifetime of different shapes grounding grids, but it is steep after the period to 20 -year service lifetime.

However, according to the guidelines given in IEEE standard 80 -2000[9], "the increase of $50 \mathrm{~Hz}$ ground resistance of the whole grounding grid due to corrosion below $2.5 \Omega$ is acceptable". Hence, at resistance base value $R_{\text {Base }}=1000 \Omega$ of the per-unit system as numerical generalization method, the acceptable increase resistance will be 0.0025 p.u.

It may be remained from Fig. 17 that the increase of $50 \mathrm{~Hz}$ grounding grid $(1 \times 1)$ without vertical rods ground resistance $\left(\Delta R_{G}\right)$ of the designed grounding gird due to corrosion will be 0.0027 p.u. in 10 years after being buried. The value exceeds the maximum acceptable value at this time; hence, the performance of the grounding grid is not satisfactory. Then the estimated service lifetime of the designed grounding grid $(1 \times 1)$ without vertical rods is 9 years.

It may be remained from Fig. 17 that the increase of ground resistance $\left(\Delta R_{G}\right)$ of the designed grounding grid $(2 \times 2)$ without vertical rods due to corrosion will be 0.0026 p.u. in 13 years after being buried, then the estimated service lifetime of the designed grounding grid $(2 \times 2)$ without vertical rods is 12 years.

For the designed grounding grid $(3 \times 3)$ without vertical rods the increase of ground resistance $\left(\Delta R_{G}\right)$ due to corrosion will be 0.0031 p.u. in 17 years after being buried, the estimated service lifetime of the designed grounding grid is 16 years.

However, the increase of $50 \mathrm{~Hz}$ ground resistance $\left(\Delta R_{G}\right)$ of the designed grounding grid $(1 \times 1)$ with 4 vertical rods due to corrosion will be 0.0033 p.u. in 12 years after being buried The estimated service lifetime of the designed grounding grid is 11 years.

Moreover, the increase of ground resistance $\left(\Delta R_{G}\right)$ of the designed grounding grid $(2 \times 2)$ with 9 vertical rods due to corrosion, Fig. 17, will be 0.0030 p.u. in 16 years, then the estimated service lifetime of the designed grounding grid is 15 years.

For the designed grounding grid $(3 \times 3)$ with 16 vertical rods the increase of ground resistance $\left(\Delta R_{G}\right)$ due to corrosion, Fig. 17 , will be 0.0029 p.u. in 19 years after being buried then the estimated service lifetime of the designed grounding grid is 18 years.

\section{CONCLUSION}

The performances of steel grounding grids according to corrosion effect at a certain year of the service lifetime are proposed in this paper.

The current distribution of each grounding grid segment at any year next to the grounding grid which is buried in two layers soil is also given in this paper.

In order to measure the increase of self-ground resistance of conductor segment at a certain corrosion degree, the corrosion of the conductor segment need to be accelerated to a certain degree in a short time, a corrosion acceleration method is presented in this paper and the measurement method is also given.

Service lifetime estimation, as a problem or task faced by the industry (especially the power industry), is indicated in this paper using a mathematical model of the grounding grid. Moreover, a scheme that can estimate the service lifetime of the grounding grid is proposed. A case study to illustrate how the scheme to work is also given in this paper.

The estimated service lifetimes of studied different shapes grounding grids are:

9 years for the ground grid $(1 \times 1)$ without rods, 11 years for the ground grid $(1 \times 1)$ with 4 rods with percentage increase by the amount of $22.22 \%, 12$ years for the ground grid $(2 \times 2)$ without rods, 15 years for the ground grid $(2 \times 2)$ with 9 rods with percentage increase by the amount of $25 \%, 16$ years for the ground grid $(3 \times 3)$ without rods and 18 years for the ground grid $(3 \times 3)$ with 16 rods with percentage increase by the amount of $12.5 \%$ of the grounding grids service lifetimes according to corrosion effects.

It may be concluded that the percentages that the grounding grids with vertical rods have more service lifetime than the grounding grids without vertical rods using same dimensions and under the same soil conditions.

\section{REFERENCES}

[1] Osama El. Gouda and Hanan M.Ahmed, "Earth surface potentials and GPR for grids having different conductors' distributions buried in different layer soil structures", Proceedings of the $14^{\text {th }}$ International Middle East Power Systems Conference (MEPCON'10), Cairo University, Egypt, December 19-21, 2010.

[2] S. S. Dessouky, S.Ghoneim and S. Awad. "Grounding resistance, step and touch voltages for a driven vertical rod into two-layer model soil", International Conference on Power System Technology. 2010.

[3] Shengxin Huang, Zhihong Fu and Qian Wang," Service life estimation for the small and medium-sized earth grounding grid", IEEE Transactions on Industry Applications, IEEE 2015

[4] P. K. Sen, and N. K. Mudarres, "Corrosion and steel grounding" Proceedings of the Twenty-Second Annual North American, Power Symposium, 1990.

[5] F. Dawalibi, "Electromagnetic fields generated by overhead and buried short conductors part 2-ground networks", IEEE Transactions on Power Delivery, vol. 1, no. 4, pp. 112-119, 1986.

[6] F. P. Dawalibi, and F. Donoso, "Integrated analysis software for grounding, EMF, and EMI", IEEE Computer Applications in Power, vol. 6 , no. 2 , pp. 19-24, 1993.

[7] J. Guemes, and F. Hernando, "Method for calculating the ground resistance of grounding grids using FEM", IEEE Transactions on Power Delivery, vol. 19, no. 2, pp. 595-600, 2004.

[8] F. Freschi, M. Mitolo, and M. Tartaglia, "An effective semianalytical method for simulating grounding grids" , IEEE Transactions on Industry Applications, vol. 49, no. 1, pp. 256-263, 2013.

[9] IEEE Guide for safety in AC substation grounding, IEEE Standard 80-2000, 2000, pp. i-192.

[10] F. Freschi, M. Mitolo, and M. Tartaglia, "Interferences Phenomena Between Separate Grounding Systems", IEEE Transactions on Industry Applications, vol. 50, no. 4, pp. 2853-2860, 2014.

[11] M. D. Bryant, and M. Jin, "Time-wise increases in contact resistance due to surface-roughness and corrosion", IEEE Transactions on Components Hybrids and Manufacturing Technology, vol. 14, no. 1 , pp. 79-89, Mar 1991

[12] J. Wu, and M. G. Pecht, "Contact resistance and fretting corrosion of lead-free alloy coated electrical contacts", IEEE Transactions on Components and Packaging Technologies, vol. 29, no. 2, pp. 402410, Jun 2006. 
[13] C.-Y. Bai, M. D. Ger, and M.-S. Wu, "Corrosion behaviors and contact resistances of the low-carbon steel bipolar plate with a chromized coating containing carbides and nitrides", International Journal of Hydrogen Energy, vol. 34, no. 16, pp. 6778-6789, Aug 2009.

[14] S. Masui, S. Sawada, T. Tamai, Y. Hattori, K. Iida, "Measurement of contact resistance distribution in fretting corrosion track for the tin plated contacts", IEEE 57th Holm Conference on Electrical Contacts, Electrical Contact, 2011.

[15] J. L. He, R. Zeng, Y. Q. Gao, Y. P. Tu, W. M. Sun, J. Zou, and Z. C. Guan, "Seasonal influences on the safety of substation grounding system,", IEEE Transactions on Power Delivery, vol. 18, no. 3, pp. 788-795, Jul 2003.

[16] R. J. Heppe, "Computation of potential at surface above an energized grid or other electrode, allowing for non-uniform current distribution", IEEE Transactions on Power Apparatus and Systems, 1979; Vol. PAS-98, No.6. 
Faculty of Energy Engineering - Aswan University - Aswan - Egypt 